\title{
PENGARUH DISIPLIN KERJA, KEMAMPUAN DAN LINGKUNGAN KERJA TERHADAP PENERAPAN ISO 9001 DI SMK AKPELNI SEMARANG
}

\author{
Budi Purnomo $^{1}$, Karjono², Iik Suryati Azizah ${ }^{3}$ \\ 1, Program Studi Teknika. Politeknik Bumi Akpelni Semarang \\ ${ }^{2,3}$ Program Studi Ketatalaksanaan Pelayaran Niaga dan kepelabuhan Politeknik Bumi Akpelni \\ Email: budi.p@akpelni.ac.id
}

\begin{abstract}
Abstrak
Setiap organisasi dituntut untuk dapat mengoptimalkan sumber daya yang ada dalam organisasi tersebut terutama sumber daya manusianya. Pengelolaan sumber daya manusia tidak lepas dari faktor karyawan yang diharapkan dapat berprestasi sebaik mungkin demi mencapai tujuan organisasi. Penelitian ini dilakukan di SMK Akpelni Semarang yang bertujuan untuk mengetahui pengaruh disiplin kerja, kemampuan kerja dan lingkungan kerja terhadap ISO 9001. Sampel yang digunakan dalam penelitian sebanyak 70 responden. Data yang diperoleh diolah dengan menggunakan analisis deskriptif dan analisis statistik kuantitatif. Analisis kuantitatif menggunakan analisis regresi berganda untuk mengetahui pengaruh variabel independent terhadap variabel dependent, namun sebelum dilakukan uji tersebut dilakukan dahulu uji validitas dan uji reliabilitas serta uji persyaratan. Hasil penelitian menunjukkan disiplin kerja, kemampuan kerja dan lingkungan kerja secara bersama-sama berpengaruh terhadap ISO 9001 di SMK Akpelni Semarang.
\end{abstract}

Kata kunci: disiplin kerja, kemampuan kerja, lingkungan kerja dan ISO 9001

\section{PENDAHULUAN}

Setiap organisasi dituntut untuk dapat mengoptimalkan sumber daya yang ada dalam organisasi tersebut terutama sumber daya manusianya. Pengelolaan sumber daya manusia tidak lepas dari faktor karyawan yang diharapkandapat berprestasi sebaik mungkin demi mencapai tujuan organisasi. Karyawan merupakan asset utama organisasi dan mempunyai peran yang strategis didalam organisasi yaitu sebagai pemikir, perencana, dan pengendali aktivitas organisasi. Melihat pentingnya karyawan dalam organisasi, maka diperlukan perhatian lebih serius terhadap tugas karyawan yang dikerjakan sehingga tujuan organisasi tercapai. Sebagai salah satu sekolah maritim swasta yang adadi Indonesia,

SMK Pelayaran AKPELNI berusaha terus mengembangkan mutu pendidikan maupun pelayanannya. Pelayanan terhadap customer tidak bisa terlepas dari Penerapan ISO para karyawannya. Namun terdapat beberapa kendala pelayanan karyawan yang belum maksimal. Misalnya meninggalkan tugas pada saat jam kerja, terlambat dan lain sebagainya. Untuk menanggapi kondisi tersebut, agar organisasi bisa bertahan dan mengembangkan usahanya maka harus selalu meningkatkan mutu pelayanan kepada pelanggan melalui peningkatan Penerapan ISO.

Salah satu standar sistem manajemen mutu yang telah berkembang dinegara maju dan berkembang adalah dengan penerapan ISO 9001:2008. Standar ini merupakan sarana atau alat untuk mencapai tujuan yang diharapkan mampu menjawab tantangan globalisasi untuk mencapai tujuan organisasi yaitu efektifitas dan efisiensi.Untuk mengetahui efektifitas dan efisisensi terhadap Penerapan ISO 9001nya pada tahun ini SMK Pelayaran AKPELNI merasa perlu menerapkan ISO 9001:2008. ISO 9001:2008

Dalam lingkungan dunia
pendidikan, yang dimaksud dengan
penjaminan mutu adalah pelayanan yang
diberikan oleh perguruan tinggi terhadap
stakeholder yang terdiri dari siswa, orang
tua mahasiswa, alumni dan pengguna
lulusan. Bahwa dalam rangka memelihara
manajemen mutu pendidikan tinggi di
Indonesia secara berkelanjutan, setiap


satuan pendidikan tinggi harus menerapkan system penjaminan mutu internal (Internal Quality Assurance) secara utuh dan menyeluruh pada setiap aspek kegiatannya. Keharusan untuk menerapkan Sistem

Penjaminan Mutu Internal dalam penyelenggaraan dan pengelolaan pendidikan tinggi tersebut secara tegas telah tertuang dalam Peraturan pemerintah No. 19 tahun 2005 tentang Standar Nasional Pendidikan pasal 91 ayat (1) yang menyatakan bahwa setiap satuan pendidikan pada jalur formal dan informal wajib melakukan penjaminan mutu pendidikan. Untuk itu, setiap organisasi atau lembaga perlu menyiapkan kerangka sistem mutu lembaganya kearah yang diinginkan sesuai sasaran atau tujuan akhir yang ditetapkan oleh lembaga tersebut, dalam pengertian bahwa tujuan atau sasaran mutu dari suatu lembaga untuk mampu mencapai kesesuaian dengan keinginan yang diharapkan dari pelanggan.

Sertifikasi ISO 9001:2008, merupakan suatu reformasi birokrasi kearah yang lebih baik, dimana para karyawan menjadi lebih disiplin dan lebih terukur Penerapan ISOnya. ISO adalah suatu badan yang mengatur sertifikasi atau mengesahkan suatu standar. ISO dibuat karena keinginan perusahaan dari berbagai macam bidang usaha untuk memuaskan pelanggannya, yaitu meningkatkan mutu kerja dan pelayanan sesuai dengan standar yang ditetapkan. Standard internasional ini menentukan persyaratan bagi sistem manajemen mutu dimana sebuah organisasi perlu menunjukkan kemmampuannya secara konsisten menghasilkan produk yang memenuhi persyaratan pelanggan dan perundangan dan peraturan yang berlaku.

\section{LANDASAN TEORI Struktur Organisasi}

SMK Pelayaran "AKPELNI"

Semarang dipimpin oleh seorang Kepala Sekolah, dibantu oleh 4 orang Wakil Kepala Sekolah yang bertanggung jawab dalam urusan-urusan Kurikulum, Sarana Prasarana, Ketarunaan dan Hubungan masyarakat, serta 2 orang ketua kompetensi keahlian nautika dan teknika.

Struktur Organisasi SMK Pelayaran "AKPELNI" Semarang ditunjukkan pada gambar 1 berikut ini :

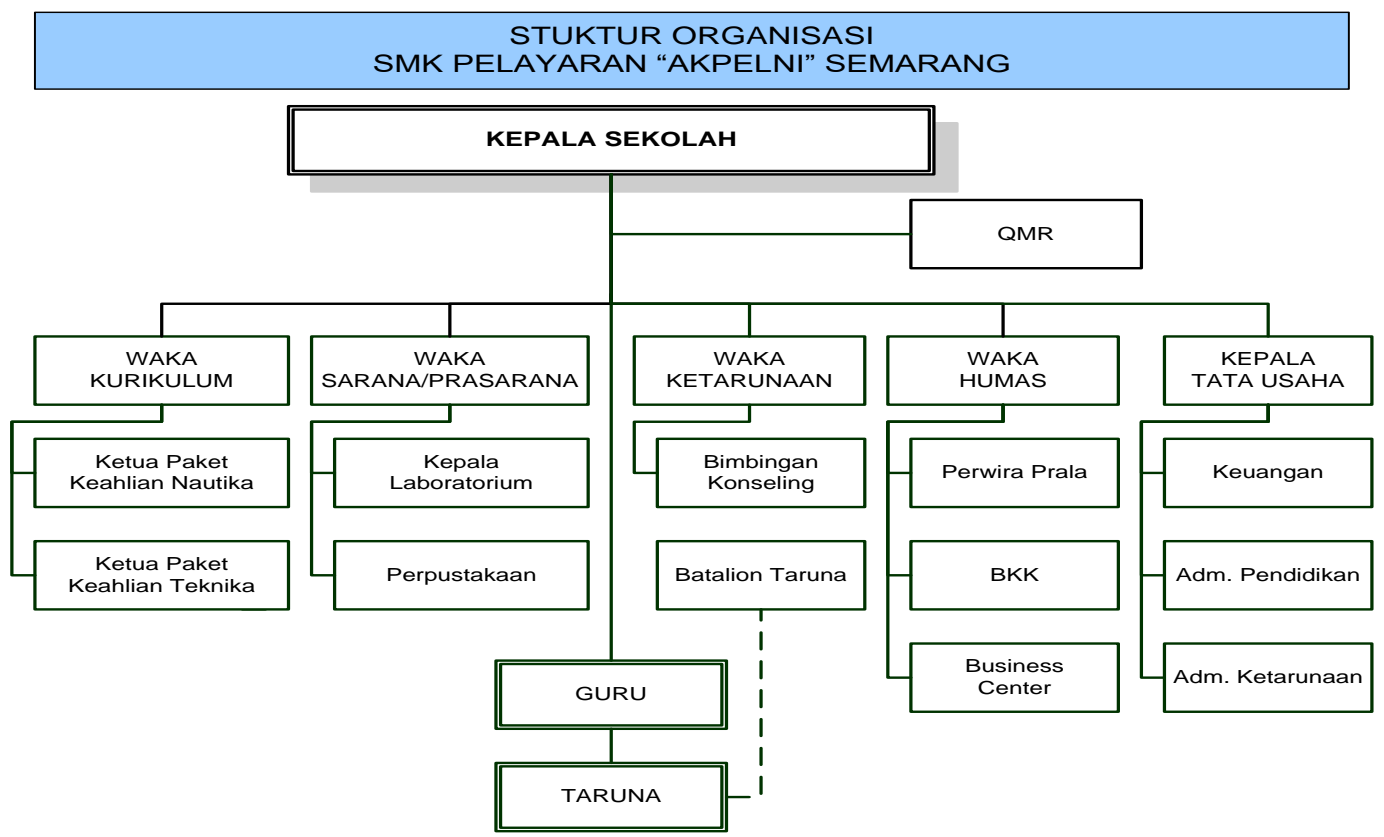

Gambar 1 : Struktur Organisasi SMK P AKPELNI 
Visi

Menjadikan SMK Pelayaran "AKPELNI" Semarang yang mampu menghasilkan pelaut- pelaut yang bertaraf Nasional dan Internasional serta berahklak mulia.

\section{Misi}

1) Menerapkan Kurikulum yang mengacu pada Standar Isi Pendidikan dan Mutu Kepelautan

2) Menyediakan Sarana Prasarana Pembelajaran sesuai StandarNasional Pendidikan Dan Quality Standard System

3) Menyiapkan Pendidik dan Tenaga Kependidikan sesuai Standar Nasional Pendidikan Dan Quality Standard System.

\section{Kurikulum}

Kurikulum yang digunakan adalah sebagai berikut:

\section{1) Normatif dan Adaptif}

Menggunakan Kurikulum Tingkat Satuan Pendidikan (KTSP). Di tahun 2014 SMK Pelayaran "AKPELNI" Semarang wajib menggunakan Kurikulum 2013 (K13)

\section{2) Produktif}

Menggunakan kurikulum Pendidikan Diklat Pelaut Menengah Nomor :

SK656/DL.002/VI/Diklat/2010 Tahun 2014 sudah menggunakan kurikulum Hubla yang sudah disesuaikan dengan PM 70.

\section{Pengajar}

Pengajar tetap untuk kurikulum "Normatif/Adaptif" adalah 9 orang. Pengajar tetap untuk kurikulum Produktf adalah 12 orang untuk Nautika dan 5 orang untuk Teknika.

\section{METODE}

Penelitian ini dilaksanakan pada bulan Juni - Oktober 2015 di SMK Pelayaran AKPELNI. Metode yang digunakan dalam penelitian adalah metode survei dengan analisis kuantitatif menggunakan analisis regresi linier berganda. Sampel yang digunakan dalam penelitian sebanyak 70 responden.

Data primer meliputi tanggapan responden (karyawan) sehubungan dengan sehubungan dengan kinerja,
Kemampuan, Lingkungan Kerja serta Infrastruktur. Skala pengukuran indikator dalam penelitian ini menggunakan skala likert, yaitu mulai dari yang terkecil berarti sangat tidak setuju diberi nilai/skor 1 (satu) sampai dengan nilai terbesar yaitu sangat setuju diberi nilai/skor 5 (lima).

Penelitian ini dianalisis dengan menggunakan prosedur analisis statistik deskriptif yaitu analisis dengan menggunakan tabel, grafik, diagram, ratarata untuk menggambarkan objek yang diteliti. Analisis statistik inferensial yaitu analisis yang dilakukan untuk menguji hipotesis penelitian.

\section{HASIL DAN PEMBAHASAN \\ Pengaruh Disiplin Kerja Terhadap Penerapan ISO 9001}

Disiplin kerja berpengaruh positif dan signifikan terhadap Penerapan ISO 9001. Indikator yang digunakan yaitu adanya kejelasan dan penjelasan tentang pola sikap, tindakan dan perilaku yang diinginkan dari setiap anggota organisasi, Adanya usaha pencegahan jangan sampai para pegawai berperilaku negatif, pengenaan sanksi dilakukan secara obyektif, Sifat sanksi sesuai bobot pelanggaran yang dilakukan, pengenaan sanksi harus pula bersifat mendidik agar terjadi perubahan sikap dan perilaku di masa depan serta Pengenaan sanksi mempunyai nilai pelajaran dalam arti mencegah pegawai lain melakukan pelanggaran yang sama.

Manajemen mendorong para pimpinan organisasi untuk memenuhi tuntutan berbagai ketentuan tersebut, dengan kata lain disiplin kerja terhadap pegawai adalah suatu bentuk pelatihan yang berusaha memperbaiki dan membentuk pengetahuan, sikap dan perilaku pegawai sehingga para pegawai secara sukarela bekerja secara kooperatif dengan pegawai lainnya, serta meningkatnya prestasi kerja 


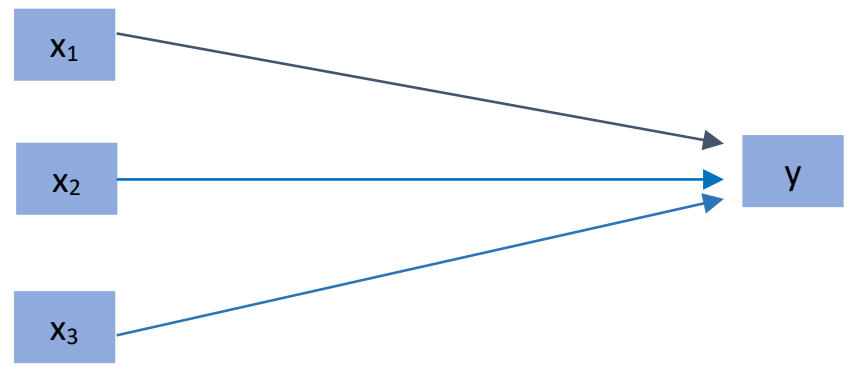

Gambar 2 : Kerangka berfikir

\section{Pengaruh Kemampuan Terhadap Penerapan ISO 9001}

Kemampuan berpengaruh positif dan signifikan terhadap Penerapan ISO 9001. Indikator yang digunakan yaitu stamina, kecekatan tangan, kekuatan tangan, kekuatan tungkai, kemampuan fisik, kemampuan berhitung, pemahaman verbal, kecakapan perspektual, penalaran induktif, visualisasi ruang serta daya ingatan.

Kemampuan dimaksudkan sebagai kesanggupan (capasity) karyawan untuk melaksanakan pekerjaan. Kemampuan mengandung berbagai unsur seperti keterampilan manual/ fisik dan intelektual, bahkan sampai kepada sifatsifat pribadi yang dimiliki. Unsur ini juga mencerminkan pendidikan, latihan dan pengalaman yang dituntut sesuai rincian kerja. Kemampuan sesungguhnya merupakan suatu unsur pelaksanaan kerja yang diperlukan untuk memungkinkan para karyawan bekerja dengan cara tertentu.

\section{Pengaruh Lingkungan Kerja Terhadap Penerapan ISO 9001}

Lingkungan kerja berpengaruh terhadap penerapan ISO 9001. Indikator yang digunakan yaitu ruang kerja, ruang Kelas, laboratorium, fasilitas Ibadah, hubungan dengan teman serta hubungan dengan pimpinan.

Pencapaian prestasi dalam menyelesaikan tugas dan kewajiban seseorang berkaitan dengan kemampuan menyelesaikan tujuan yang ingin dicapai dalam bidang pekerjaan tertentu (challenging goal). Atas dasar pengertian tersebut, sebagian orang menyenangi tujuan-tujuan yang menantang (tujuan yang cukup berat tetapi masih mungkin dicapai), dan sebagian lagi menyenangi tujuan yang moderat maupun rendah.

Kemampuan seseorang diperlukan untuk menyelesaikan suatu pekerjaan. Ini berarti bahwa dalam menyelesaikan suatu pekerjaan selalu masih tersedia suatu tingkatan kemampuan yang belum dipergunakan oleh seseorang.

\section{KESIMPULAN}

Hasil penelitian dapat disimpulkan bahwa disiplin kerja berpengaruh terhadap ISO 9001, kemampuan kerja berpengaruh terhadap ISO 9001, lingkungan kerja berpengaruh terhadap ISO 9001 serta disiplin kerja, kemampuan kerja dan lingkungan kerja secara bersama-sama berpengaruh terhadap ISO 9001 di SMK Akpelni Semarang

\section{DAFTAR PUSTAKA}

Disiplin kerja, kemampuan kerja dan lingkungan kerja secara bersamasama berpengaruh terhadap ISO 9001 di SMK Akpelni Semarang.

Gibson, J. James. 2001. Organisasi, Perilaku, Struktur, dan Proses. Alih Bahasa: Savitri Soekisno dan Agus Dharma. Jakarta: Erlangga.

Goleman, Daniel. 2007. Emotional Intellegence. Diterjemahkan oleh $\mathrm{T}$. Hermaya. Jakarta: Gramedia Pustaka Utama 
Stein, Steven J., dan Book, Howard E. 2002. The EQ Edge: Emotional Intelligence and Your Success.

Diterjemahkan oleh Trinanda Rainy Januasari dan Yudhi Murtopo. Bandung: Kaifa.

Sterrs, R.M. 2002. “Task-Goal Atributes, Achievement, and Supervisory
Performance", Organizational Behavior and Human Performance, Juni, hal. 392-403.

Wahjosumidjo. 2001. Kepemimpinan dan Motivasi. Jakarta: Ghalia Indonesia. 